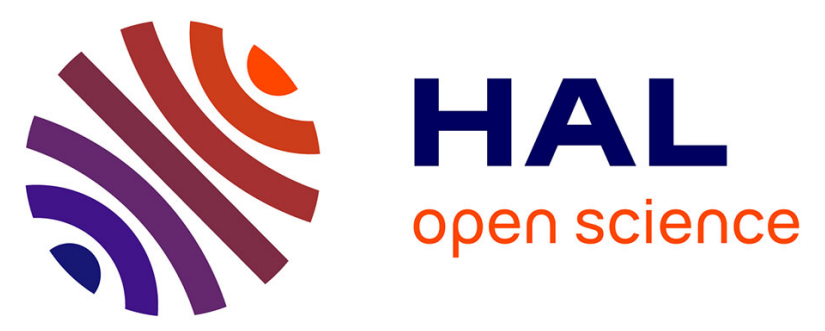

\title{
Role of DNA Repair Variants and Diagnostic Radiology Exams in Differentiated Thyroid Cancer Risk: A Pooled Analysis of Two Case-Control Studies
}

Monia Zidane, Thérèse Truong, Fabienne Lesueur, Constance Xhaard, Emilie Cordina-Duverger, Anne Boland, Hélène Blanché, Catherine Ory, Sylvie Chevillard, Jean-François Deleuze, et al.

\section{To cite this version:}

Monia Zidane, Thérèse Truong, Fabienne Lesueur, Constance Xhaard, Emilie Cordina-Duverger, et al.. Role of DNA Repair Variants and Diagnostic Radiology Exams in Differentiated Thyroid Cancer Risk: A Pooled Analysis of Two Case-Control Studies. Cancer Epidemiology, Biomarkers and Prevention, 2021, 30 (6), pp.1208-1217. 10.1158/1055-9965.EPI-20-1142 . hal-03378112

\section{HAL Id: hal-03378112 \\ https://hal.univ-lorraine.fr/hal-03378112}

Submitted on 14 Oct 2021

HAL is a multi-disciplinary open access archive for the deposit and dissemination of scientific research documents, whether they are published or not. The documents may come from teaching and research institutions in France or abroad, or from public or private research centers.
L'archive ouverte pluridisciplinaire HAL, est destinée au dépôt et à la diffusion de documents scientifiques de niveau recherche, publiés ou non, émanant des établissements d'enseignement et de recherche français ou étrangers, des laboratoires publics ou privés. 
1 Role of DNA repair variants and diagnostic radiology exams in differentiated thyroid

2 cancer risk: a pooled analysis of two case-control studies

3

4 Monia, Zidane ${ }^{1,2,3}$, Thérèse, Truong ${ }^{1,2,3}$, Fabienne, Lesueur ${ }^{4}$, Constance, Xhaard ${ }^{5,6}$,

5 Emilie, Cordina-Duverger ${ }^{1,2,3}$, Anne, Boland ${ }^{7}$, Hélène, Blanché ${ }^{8,9}$, Catherine, Ory ${ }^{10}$,

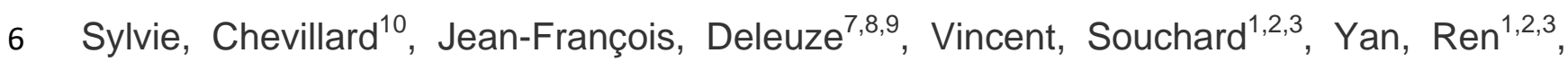

7 Mohammed, Zakarya, Zemmache ${ }^{1,2,3}$, Sandra, Canale ${ }^{2}$, Françoise, Borson-Chazot ${ }^{11}$,

8 Claire, Schvartz ${ }^{12}$, Eugènia, Mariné, Barjoan ${ }^{13}$, Anne-Valérie, Guizard ${ }^{14,15}$, Pierre,

9 Laurent-Puig $^{16}$, Claire, Mulot ${ }^{16}$, Julie, Guibon ${ }^{1,2,3,4}$, Mojgan, Karimi ${ }^{1,2,3}$, Martin,

10 Schlumberger ${ }^{2,3}$, Elizabeth, Adjadj ${ }^{1}$, Carole, Rubino ${ }^{1,2,3}$, Pascal, Guenel ${ }^{1,2,3}$, Jean-

11 Baptiste, Cazier ${ }^{17}$, Florent, de Vathaire ${ }^{1,2,3}$

12 1) INSERM, Centre for Research in Epidemiology and Population Health (CESP),

1394800 Villejuif, France

14 2) Université Paris-Sud Orsay, 94800 Villejuif, France

15 3) Gustave Roussy, 94800 Villejuif, France

16 4) Inserm, U900, Institut Curie, Université PSL, Mines ParisTech, Paris, France

17 5) INSERM Centre d'Investigation Clinique CIC-P 1433, CHRU Nancy, France

18 6) INSERM U1116, FCRIN INI-CRCT, Lorraine Université, Nancy, France

19 7) Université Paris-Saclay, CEA, Centre National de Recherche en Génomique 20 Humaine, 91057, Evry, France

21 8) Fondation Jean Dausset-CEPH (Centre Etude du Polymorphisme Humain), Paris, 22 France

23 9) Laboratory of Excellence GENMED (Medical Genomics) 
10) CEA, Direction de la Recherche Fondamentale, Institut de Biologie François Jacob, iRCM, SREIT, Laboratoire de Cancérologie Expérimentale (LCE), Université Paris-Saclay, 92265, Fontenay-aux-Roses, France

11) Rhône-Alpes Thyroid Cancer Registry, Cancer Research Center of Lyon (UMR INSERM 1052, CNRS 5286), RTH Laennec Faculty of Medicine, University of Lyon, Lyon,

12) Thyroid Cancer Registry of Champagne-Ardennes, Institut Jean Godinot, Reims, Cancer Registry of Isère, Meylan,

13) Public Health Department, University Hospital Nice, Nice,

14) Registre Général des Tumeurs du Calvados, Centre François Baclesse, Caen, France

15) U1086 INSERM-UCN "ANTICIPE", Caen, France

16) Centre de Recherche des Cordeliers, INSERM, Sorbonne Université, USPC, Université Paris Descartes, Université Paris Diderot, EPIGENETEC, Paris, France

17) Institute of Cancer and Genomic Sciences, Centre for Computational Biology, University of Birmingham, Birmingham, B15 2TT, UK.

moniazidane@gmail.com, therese.truong@inserm.fr, fabienne.lesueur@curie.fr, c.xhaard@chru-nancy.fr, emilie.cordina@inserm.fr, boland@cng.fr, helene.blanche@fjdceph.org, catherine.ory@cea.fr, sylvie.chevillard@cea.fr, deleuze@cng.fr, vincent.souchard@gustaverouss.fr, renyan0472@hotmail.com, zemmache.zakarya@gmail.com, sandra.canale@gustaveroussy.fr, francoise.borsonchazot@chu-lyon.fr, claire.schvartz@reims.unicancer.fr, marine-barjoan.e@chu-nice.fr, av.guizard@baclesse.fr, pierre.laurent-puig@parisdescartes.fr, claire.mulot@inserm.fr, julie.guibon@inserm.fr, mojgan.karimi@inserm.fr, martin.schlumberger@gustaveroussy.fr, elisabeth.adjadj@inserm.fr, 
50 florent.devathaire@gustaveroussy.fr

51 Running title: Role of DNA repair variants in thyroid cancer

52 Keywords: thyroid cancer genetics, thyroid epidemiology, ionizing radiations, DNA repair, 53 cancer susceptibility

54 Corresponding author: Dr. Florent de Vathaire, mailing address: Radiation Epidemiology 55 Group Unit1018INSERM Bâtiment B2M Institut Gustave Roussy 39, rue Camille 56 Desmoulins 94805 Villejuif cedex Phone number: +33142115457, Fax number: $57+33142115315$, Mobile: +33688093185, email address:

58 florent.devathaire@gustaveroussy.fr

59 The authors declare no potential conflicts of interest 
Abstract

Background: Given the increased use and diversity of diagnostic procedures, it is important to understand genetic susceptibility to radiation-induced thyroid cancer. Methods: Based on self-declared diagnostic radiology examination records in addition to existing literature, we estimated the radiation dose delivered to the thyroid gland from diagnostic procedures during childhood and adulthood in two case-control studies conducted in France. A total of 1071 differentiated thyroid cancer (DTC) cases and 1188 controls from the combined studies were genotyped using a custom-made Illumina OncoArray DNA chip. We focused our analysis on variants in genes involved in DNA damage response and repair pathways, representing a total of 5817 single-nucleotide polymorphisms in 571 genes. We estimated the odds ratio per milli-Gray (OR/mGy) of the radiation dose delivered to the thyroid gland using conditional logistic regression. We then used an unconditional logistic regression model to assess the association between DNA repair gene variants and DTC risk. We performed a meta-analysis of the two studies. Results: The OR/mGy was 1.02 (95\% Cl: 1.00, 1.03). We found significant associations between DTC and rs7164173 in CHD2 ( $\left.p=5.7910^{-5}\right)$, rs6067822 in NFATc2 $\left(p=9.2610^{-5}\right)$, rs1059394 and rs699517 both in ENOSF1/THYS, rs12702628 in RPA3, and an interaction between rs7068306 in MGMT and thyroid radiation doses ( $\mathrm{p}=$ $3.4010^{-4}$ ). Conclusions: Our results suggest a role for variants in CDH2, NFATc2, ENOSF1/THYS, RPA3 and MGMT in DTC risk.

Impact: CDH2, NFATc2, ENOSF1/THYS and RPA3 have not previously been shown to be associated with DTC risk. 


\section{Introduction}

Differentiated thyroid cancer (DTC) is the most common cancer of the endocrine system (1). The registered incidence of DTC has recently been increasing, especially in developed countries mostly due to increased screening (2). Exposure to thyroid ionizing radiation (IR) during childhood was the first risk factor linked with DTC, an association that has been well characterized over several decades (3-8).

In a pooled study performed on doses higher than $\geq 1 \mathrm{~Gy}(9,10)$, the excess of DTC relative risk per Gray (ERR/Gy) delivered to the thyroid gland during childhood ranged between 5 and 10. When restricting the pooled analysis to doses lower than 0.2 Gy, however, the ERR/Gy was slightly higher (11). A higher magnitude of excess risk for low dose exposure during childhood was also observed in a cohort study of Japanese atomic bomb survivors (12). Nevertheless, some uncertainties remain about how the recent increase in the use of diagnostic procedures involving irradiation, such as CT (computerized tomography), might affect DTC incidence $(13,14)$.

Despite being more subject to recall bias than cohort studies, case-control studies may be more helpful for improving understanding of thyroid low-dose radiation risk since casecontrol studies utilize a high number of cases and permit a more detailed investigation of a high number of potential risk cofactors, which are costlier to investigate in cohort studies. Since DTC risk after low radiation dose exposure is also likely modulated by individual susceptibility, investigating the association between DNA variants and DTC risk after low radiation dose could also facilitate an improved understanding of this risk. IR exposure causes DNA damage as well as other physical and chemical biomolecule alterations. DNA double-strand breaks (DSBs) are a characteristic cellular response to IR exposure (15). Exposure to low-dose IR (from levels 50mGy and lower) from X-ray 
examinations has been demonstrated to increase the risk of chromosomal translocation (16), suggesting the possibility of long-term adverse health effects.

DSBs trigger the DNA repair system, but the effect of these DSBs varies with cumulative exposures and individual susceptibility. To our knowledge, only one published study has investigated an interaction between genetic background and the radiation-related DTC risk after diagnostic radiation exposure (17). This study identified 24 single-nucleotide polymorphisms (SNPs) with a p-value of variant-RI doses interaction was $<0.05$ for all types of DTC cases (papillary and follicular). Currently, few genes including FOXE1, ATM, and LIG1 have been associated with DTC risk after IR exposure, but most published studies of these genes were conducted in highly irradiated populations. Moreover, these identified genes were associated with sporadic DTC (18).

Given the increasing use of diagnostic radiology exams and the proliferation of radiology procedure types, it is important to explore the side effects of multiple low-radiation exposures, such as potential effects on DTC development, especially for patients exposed at a young age.

In the current study, we investigated the association between diagnostic low-dose IR exposures and DTC risk. We quantified the doses delivered to the thyroid gland during childhood and adulthood in two French case-control studies. We also investigated the role of genetic variants located in 604 DNA damage signaling and repair genes in modifying the effect of exposure to diagnostic procedure radiation on DTC risk.

\section{Materials and methods}

\subsection{Case-control studies}

Our study included cases and controls from two studies conducted in distinct regions from metropolitan France. 
131 The CATHY study (19) was a case-control study conducted in Marne, Ardennes, and 132 Calvados, three French administrative areas covered by a cancer registry. Eligible cases were all DTC patients aged 25 years and older that were diagnosed between 2002 and 2007 and resided in these areas. Controls were recruited by selecting and contacting telephone numbers at random, then frequency-matching the individuals to patients by sex and five-year age groups; controls were randomly selected among healthy individuals residing in the same study areas at the time of the matched cases diagnoses. From the 621 cases and 706 controls initially included in the CATHY study, saliva DNA samples (Oragene® DNA testing kit) were available for 583 cases and 643 controls.

The Young-Thyr study (20) is a case-control study conducted in eastern regions of France: Alsace, Champagne-Ardennes, Corse, Franche-Comté, Lorraine, Rhône-Alpes, and Provence-Alpes-Côte d'Azur. Eligible cases were all DTC patients diagnosed with DTC between January 1st, 2002, and December $31^{\text {st }}, 2006$ that were younger than 35 years of age with their main residence in a region of eastern France. Controls were selected from the general population and individually matched to a single patient of the same sex, year of birth (within one year), and region of residence during the year when the patient was diagnosed with cancer. From the 805 cases and the 876 controls included in the Young-Thyr study, DNA from saliva (Oragene®) was available for 715 cases and 692 controls.

Participants from both studies answered similar questionnaires that were collaboratively developed. Information on a personal and familial history of thyroid disease, hormonal and reproductive factors, weight, height, dietary habits, tobacco smoking, and medical history was collected during in-person interviews. Participants from both studies gave their informed written consent before being interviewed by trained interviewers. Both 
studies were approved by the Ethics Committee and the French National Commission for Data Protection (CNIL).

Clinical and epidemiological data from both studies were harmonized and aggregated in one database. During this process, 30 subjects were excluded because they were duplicates in the two studies.

\subsection{Radiologic procedure history}

In the questionnaire, participants were asked to report their history of diagnostic radiology examinations by providing the year and the reason for each examination. The exams considered were conventional radiography, CT scans, and nuclear medicine. Examinations linked to investigating thyroid pathology were excluded and were not considered in the dose estimation or any analysis. Examinations carried out during childhood (before the age of 20 years) and adulthood (over 20 years) were analyzed separately. All procedures reported by participants were classified by period (before $1980,1980-1989,1990$, and after) to take into account the development of radiologic procedure technology over this time.

\subsection{Thyroid radiation dose estimates}

To estimate the absorbed radiation doses administered to the thyroid gland for different types of diagnostic radiology examinations, we reviewed papers published up to July 2018 that included absorbed dose estimates to the thyroid. From 1970 to 2002, only one study provided estimates of absorbed doses to organs, including the thyroid gland (21), and was used to calculate dose estimates from conventional radiography.

If sex-specific data were available, a mean dose was used. Since the available data about childhood exams were very limited, specific doses were available only for children under the age of two years old without consideration of the period of exposure. Children 
179 older than two years were assumed to receive the same doses as adults. All doses per exam that were equal to or less than 0.01 mGy were considered to be null because of the magnitude of daily natural irradiation in France. Table 1 summarizes the different values used per diagnostic procedure type (conventional radiography, CT scan, nuclear medicine), per period (before 1980, 1980-1989, 1990 and after), and per age at examination ( $\leq 2$ years old, $>2$ years)

\subsection{Genotyping and quality control}

DNA was extracted from saliva samples using a semi-automated salt precipitation method. All subjects were genotyped using the Infinium OncoArray-500K BeadChip (Illumina). This array has been previously described in detail (22) and contains 499,170 SNPs. We incorporated 13,759 additional custom markers based on prior evidence of association in genes involved in relevant biological pathways, such as thyroid function.

The quality control process was applied to the data of each study separately. A threshold of $5 \%$ was applied for a missing call rate per SNP and individual. The Hardy-Weinberg equilibrium (HWE) was also assessed per SNP among controls, using an exact test with a p-value threshold at $10^{-5}$. Only SNPs with a minor allele frequency (MAF) above $5 \%$ were included in the analyses.

The FastPop $\mathrm{R}$ package was used to infer intercontinental ancestry with a principal component-derived method (23). Only individuals identified as European were kept in the genetic analyses. A total of 443 cases and 532 controls from CATHY and 629 cases and 656 controls from Young-Thyr were included in the analysis of SNPs.

SNPs of DNA damage signaling and repair genes according to the Gene Ontology database $(24,25)$ were examined. We initially selected exonic and intronic variants in 604 
genes. After the quality control steps, a total of 5817 SNPs in 571 genes were retained for the analysis (all genes are listed in the Supplementary Table S1).

\subsection{Statistical methods}

We used a conditional logistic regression model to estimate the odds ratio of DTC per mGy (OR/mGy) of radiation dose received by the thyroid gland. Because in our study, thyroid doses were very low and cell killing not likely to play signification, and because our goal was not to define the best model for thyroid cancer risk after low dose but rather the best model to investigate the interaction between thyroid radiation and genetic factors, we only investigate models with one parameter for the thyroid radiation dose. In this way, we compared a linear model $(\mathrm{OR}=\mathrm{Cst}(1+\alpha$ dose $)$ to a "constant" model without a radiation dose $(\mathrm{OR}=\mathrm{Cst})$ and other models with one parameter, such as quadratic $(\mathrm{OR}=1+\alpha$ dose 2$)$ and exponential $(\mathrm{OR}=1+\mathrm{e}(\alpha$ dose $))$, rather to traditional dose-response models used in radiation epidemiology (26). These comparisons were done using Akaike Information Criterion (AIC) (27). Similarly, we investigated the potential role of a dose-response modifier by introducing a term for interaction in the models. The analysis of the radiation dose was performed by using the PECAN module of Epiwin $\AA$ software. To assess the association between SNPs and DTC risk, odds ratios (ORs) and 95\% confidence intervals (95\% Cls) were derived from unconditional logistic regression models, assuming a log-additive model since the stratum was not considered in this step. Analyses were first conducted in the Young-Thyr study to filter our SNPs and limit the number of tests to be performed later; only the 100 SNPs with the lowest $p$ values from this step were tested in the CATHY study. We also conducted a metaanalysis combining results from both studies; overall z-statistics and p-value for these 100 top SNPs were then calculated from a weighted sum of the individual statistics. Weights were proportional to the square root of the number of individuals examined in 
each sample and selected such that the squared weights summed to 1.0 , as implemented in the METAL program (28). This step aims to improve signal detection in the genetic analysis by avoiding a large number of tests, and to substantiate homologous signals in both studies since our population is relatively limited.

To correct for multiple tests in the main effect analysis, the FDR procedure (29) was calculated for each result of the meta-analysis. We investigated the interaction between SNPs and radiation doses using the likelihood ratio test, comparing models with and without the interaction term following the same steps described above.

All analyses were adjusted for age (five-year period), sex, thyroid cancer family history (yes/no), goiter history (yes/no), radiotherapy history (yes/no), BMI (continuous), height (continuous), educational level (primary school, secondary school, bachelors or higher), smoking status (never/former smoker/smoker), number of pregnancies longer than seven months in women (three classes), and study (CATHY/Young-Thyr) only in the pooled analysis. Analyses of genetic variants were additionally adjusted for the first three principal components to take into account the population stratification. Subgroup analysis was also performed separately for papillary histological type cases and according to tumor size (microcarcinoma and macrocarcinoma).

The log-linear model poses fewer convergence problems than the linear model, for that reason the association and interaction tests between radiation doses and DNA variants were performed using a log-linear model. Since we did not apply any cut-off $p$-values for SNPs selected to be included in the meta-analysis step, in this study we chose to only show our best five results from each analysis. 
Association analyses and meta-analyses were performed using R 3.6 and METAL (28). SNPs were annotated using the VEP tool (30), and gene regions were plotted with LocusZoom software (31).

\section{Results}

Demographic characteristics of the pooled study population (Young-Thyr and CATHY) are described in Table 2. More than $75 \%$ of our population were women and nonsmokers. Papillary thyroid cancer type was the most frequent type of thyroid cancer observed, with a mean age at diagnosis younger than 40 years old. However, the mean age at diagnosis was lower in the Young-Thyr study than in the CATHY study, as shown in Supplementary Table S2 (27 years versus 51 years).

\subsection{Diagnostic radiation and thyroid cancer risk}

\subsubsection{Thyroid doses determined by diagnostic radiology examination estimates}

Estimated IR doses administered to the thyroid during childhood were lower than those given after 20 years of age. Among children, the most frequent exam was panoramic dental radiography, which was reported in 971 individuals. Nuclear medicine exams were rarely reported among children; the most frequent exam scan was bone scans reported in 14 children (Table 3). During adulthood, the most frequent conventional radiography exam was chest radiography, which was seen in $30.8 \%$ of adults. Skull CT scan was the most common computed tomography exam during adulthood. Nuclear medicine exams were also relatively rarely reported among adults (Table 3 ). The median thyroid doses delivered during childhood were lower than doses administered during adulthood. The maximum childhood estimated thyroid dose was $194.2 \mathrm{mGy}$ among the whole population, the mean among cases was $2.8 \mathrm{mGy}$ and $2.0 \mathrm{mGy}$ among controls. A total of 1672 subjects reported not having received any thyroid-irradiating diagnostic procedure during childhood. The estimated maximum dose delivered to the thyroid during adulthood in a 
274 diagnostic radiology procedure was $260.0 \mathrm{mGy}$, and the mean dose was $5.6 \mathrm{mGy}$ and 5.5 mGy among cases and controls, respectively (Supplementary Tables S3 and S4). A total of 1466 subjects did not report experiencing any thyroid-irradiating diagnostic procedures during adulthood. Detailed information on diagnostic radiology exams and thyroid doses in cases and controls in each study are shown in Supplementary Tables

S2, S3, and S4. Characteristics and thyroid doses among genotyped subgroups from both studies are presented in Table 2 . The DTC risk in relation to the radiation doses in this population is detailed in Supplementary Table S5.

\subsubsection{Differentiated thyroid cancer risk in relation to thyroid radiation doses}

Only estimated radiation dose received by the thyroid gland during childhood was found to be associated with an increased DTC risk, unlike doses received during adulthood. In the linear model, the DTC OR per mGy administered to the thyroid was equal to 1.02 $(95 \% \mathrm{Cl}: 1.00,1.03)$. When restricting the analysis to papillary thyroid carcinoma, the OR per mGy was very similar. The fit of the model was improved by the addition of a quadratic term to take into account a possible higher effect of high doses, although not significant $(p=0.06)$. No significant difference $(p>0.05)$ was found between the dose responses for men and for women. No interaction was apparent between the thyroid radiation dose and obese status, age at DTC occurrence, study, number of pregnancies, female sex, smoking status, height, or the personal radiotherapy history. In a log-linear model, the odds ratio for a dose of $1 \mathrm{mGy}$ was 1.01 (95\% Cl: $1.01,1.04)$ (Table 4). Results from a sub-analysis by tumor size, shown in Table 4, yielded similar DTC risk in relation to thyroid IR doses to these from the whole population analysis. 


\subsection{Differentiated thyroid cancer risk in relation to DNA damage repair and signaling} gene variants

298

299

300

Association analysis between DTC risk and the 5817 variants in DNA damage response genes from the Young-Thyr study including all histological types yielded only two SNPs with a p-value lower than $5 \times 10^{-4}$ : rs4962347 (chromosome 10, C10orf90) and rs16983787 (chromosome 10, SMC6). None of the top 100 variants with the lowest pvalues reached the threshold $p$-value of $5 \times 10^{-4}$ in the CATHY study. In the meta-analysis, results of the association test with DTC risk showed a significantly reduced risk for carriers of the minor allele [T]; both SNPs, rs6067822 in NFATc2 and rs7164173 in CHD2, had a p-value of $5.79 \times 10^{-5}$ and $9.26 \times 10^{-5}$ respectively, under an additive model of inheritance. Associations with both variants were in the same direction in CATHY and Young-Thyr (Table 5A). Other variants in NFATc2 present among the top 100 SNPs associated with DTC in the Young-Thyr study are described in Supplementary Figure 1. Rs7164173 was the only SNP in CHD2 among the top 100 SNPs. Rs105939 and rs699517 in ENOSF1/THYS were in our best results, but statistical significance was not achieved $\left(\mathrm{OR}_{\text {meta-analysis }}=1.30, \mathrm{p}\right.$-value meta-analysis $\left.=7.81 \times 10^{-4}\right)$. Only one variant in RPA3 (rs12702628 in 7p21.3) was found to be significantly associated with DTC risk.

When the analysis was restricted to only papillary carcinoma histological types, only rs7164173 was significant $\left(p\right.$-value meta-analysis $\left.=9.33 \times 10^{-5}\right)($ Table $5 B)$. In the NFATc2 region, two SNPs, rs77971457 and rs6067822, had respective OR meta-analysis values of 1.45 and 0.77 but did not reach the significance threshold. Rs1290997 and rs1950764 in $R A D 51 B$ had OR meta-analysis values of 0.74 and 0.60 , respectively (Table $5 \mathrm{~B}$ ). The polymorphism rs 1950764 had a $p$-value meta-analysis $>5 \times 10^{-4}$. Detailed results for SNPs in RAD51B are shown in Supplementary Figure 2. Results from the best SNPs in the macrocarcinoma analysis (Table $5 \mathrm{C}$ ) yielded two SNPs in the MLK7-AS1 gene 
(rs72625242, rs16861406) in 2q31.1 in addition to two other SNPs in chromosome 2 (PMSD1and SMC6) and the C10orf90 gene in chromosome 10. In the microcarcinoma analysis, a significant result in 2q31.1 was found (rs75361806, TLK1) (Table 5D). The best results from this later analysis also yielded three SNPs in the MACROD2 gene (20p12.1).

\subsection{Differentiated thyroid cancer risk related to the interaction between thyroid doses} and variants of DNA damage repair and signaling genes

We investigated the interaction between variants in DNA damage response genes and thyroid exposure to radiation in DTC risk. In the meta-analysis, the SNP-radiation interaction term yielded a $\mathrm{p}$-value meta-analysis $=3.4 \times 10^{-4}$ and an $\mathrm{OR}_{\text {interaction }}=0.65$ for rs7068306 in MGMT (Table 6). A second MGMT SNP, rs7087131, was also among the top 100 SNPs identified in the Young-Thyr study. Results on the modifying effect of rs7068306 genotypes on DTC risk according to diagnostic radiation exposure study separately in CATHY and Young-Thyr are presented in Supplementary Table S6.

\section{Discussion}

Our main objective was to investigate the potential genetic susceptibility to DTC after exposure to low IR doses from diagnostic procedures performed during childhood. In our study, the estimated OR/mGy for thyroid radiation doses received during childhood $(\mathrm{OR} / \mathrm{mGy}=1.02(95 \% \mathrm{Cl}: 1.00,1.03))$ was similar to the $\mathrm{OR} / \mathrm{mGy}$ values of the pooled DTC study by Veiga et al. (10) when considering analyses restricted to thyroid radiation doses lower than $100 \mathrm{mGy}(\mathrm{OR} / \mathrm{mGy}=1.010,(95 \% \mathrm{Cl}: 1.004-1.018))$ or to thyroid radiation doses lower than $200 \mathrm{mGy}(\mathrm{OR} / \mathrm{mGy}=1.011,(95 \% \mathrm{Cl}: 1.007-1.02))(11)$. Compared to the latest publication on the US radiologic technologist cohort, including 90,305 radiologic technologists in the U.S. who were followed during 1983-1998, the values of our coefficients for thyroid radiation doses received during childhood are slightly 
higher than the coefficients estimated in the general analysis and the papillary carcinoma sub-analysis (32). Our estimates are also slightly higher than estimates in both the most recent analysis among Japanese atomic-bomb survivors(12) and the IARC study of the highly contaminated area of Belarus following the Chernobyl nuclear accident (8).

The genetic analyses showed an association between DTC risk and SNPs: rs6067822 in intron 1 of NFATC2 (20q11.22), rs7164173 in intron 3 of CHD2 (15q21.3), rs1059394 (3 prime UTR variant), and rs699517 (3 prime UTR variant) both in ENOSF1/THYS (18p11.32), and rs12702628 intron variant in RPA3 (7p21.3). To our knowledge, none of these genes have previously been reported to be associated with DTC risk. The effect direction of these SNPs was similar in the Young-Thyr and CATHY studies and reached the significance threshold for the meta-analysis; furthermore, NFATC2 and CHD2 genes have been implicated in the response to ionizing and ultraviolet radiation in vitro studies $(33,34)$. Moreover, cells with mutations in $C H D 2$ were found to be defective in their ability to repair DNA damage, especially after ionizing and ultraviolet radiation exposure (34). Genes of the NFAT family encode for transcription factors, which have a role in cancer progression, and also are important for responding to ionizing and ultraviolet radiation exposure (35-37); these genes were previously found to be associated with other types of cancer risk, such as melanoma, breast, colorectal and oral cancers (38-41). Rs6067822 in NFATC2 and rs7164173 in CHD2 showed a similar stabilizing effect in general and papillary subgroup analyses. Our results from the papillary thyroid carcinoma sub-analysis yielded a significant association of rs1290997 in RAD51B with DTC risk. Another variant in this gene, rs1950764, was among our top five SNPs but did not reach the significance threshold. These findings suggest a role for $R A D 51 B$ in the etiology of radiation-related DTC. Interestingly, the $R A D 51 B$ gene was involved in DNA damage repair after ultraviolet irradiation exposure $(42,43)$ and associated with breast cancer risk 
$371(44,45)$. We report this result with great caution because 525 SNPs in this gene were 372 tested in the first step of the analysis (Supplementary Table S1).

373

An association was found between two SNPs (rs1059394 and rs699517) falling within the ENOSF1/THYS gene region. These SNPs are non-coding transcript exon variants, and this region is known to be associated with ovarian and endometrial cancers $(46,47)$.

The polymorphism rs12702628 in replication protein A3 gene (RPA3), which was associated with DTC risk in our study, has previously been found to be involved in tumorigenesis, especially in gastric cancer (48).

The macrocarcinoma and microcarcinoma analyses both yielded significant results in 2q31.1. However, since these are subgroups results, they should be taken with caution, especially for the microcarcinoma analysis due to the low number of cases.

The minor allele of MGMT rs7068306 was found to interact with thyroid IR doses during childhood in reducing the risk of DTC after exposure. The first study to report an association between an MGMT variant and radiation-related DTC risk was performed in Belarusian children exposed to radiation (49). The polymorphism rs2296675, associated with DTC risk in the Belarusian population, is located $94 \mathrm{~kb}$ from rs7068306 in intron 4 of the MGMT region. A correlation coefficient of $r^{2}=0.005$ was found between $r 57068306$ and rs2296675. In a study of a Caucasian population, Sandler et al. found an interaction between other MGMT variants: rs1762444, rs4750763, and rs12219606, and exposure to radiation from diagnostic procedures (17). These SNPs are located in intron 2 and are $244 \mathrm{~kb}, 26 \mathrm{~kb}$, and $15 \mathrm{~kb}$ from rs 7068306 , respectively. The $\mathrm{r}^{2}$ values between these three SNPs and rs7068306 are 0.009 and 0.044 (Supplementary Table S7). The $r^{2}$ values between rs7068306 and the SNPs tested in studies by Lonjou and Sandler were estimated in a European reference population of 1000 Genomes project (50). Results 
395 from the present study were obtained after estimation and quantification of thyroid doses,

396 based on a combination of self-reported radiologic procedure history and literature doses 397 separately on childhood and adulthood observations. The Sandler et al. study used a 398 different procedure since no doses were taken into account; only categories of diagnostic procedure exposure based on self-reported history were evaluated. Taken together, 400 results from these different studies highlight the role of MGMT in modulating the effect of 401 IR on cells of the thyroid.

The expression of CLIP2, a gene located on 7q11.22, has been found to be strongly linked with previous radiation exposure in thyroid cancer (51).In our study, only 22 SNPs 404 located on chromosome 7 were tested (Supplementary Table S1), of which, only two were near the CLIP2 gene region. None of these were among the 100 best SNPs in our study, since the low numbers of concerned SNPs prevented us from confirming any results about locus $7 q 11.22$.

\section{Limitations of the study}

409 Investigating the thyroid radiation dose-response from self-reported radiation examinations carried out in case-control studies is sensitive to recall bias. This is particularly true when addressing public health issues highly debated by the public, such as the health effects of irradiation. As Hallquist and Jansson previously showed, in casecontrol studies investigating the impact of self-reported diagnostic radiology procedures on DTC risk, this bias produces under-reporting of examinations by both cases and controls, but significantly more by controls; furthermore, this bias could cause an overestimate of the IR effect (52). We cannot exclude such a bias in our study, which

417 could result in an overestimation of the radiation dose effect. However, in the Young-Thyr study, we previously showed that despite DTC patients being more likely than controls to believe that the consequences of the Chernobyl accident were responsible for DTC 
420 occurrences, self-reported vegetable consumption during the two months after the

421 Chernobyl accident, known to be a major source of radioactive contamination, was

422 correlated with the status of participants, cases or controls, but not with their beliefs (53).

423 Thus, exposure could be over-reported in patients, particularly when they believe that this

424 exposure contributed to their disease. In this type of study, case and control self-

425 declarations are often impacted by recall bias, especially in terms of the number of radio diagnostic exams and images in the present study. Despite these caveats, case-control studies could help to improve understanding of the risks associated with low-dose IR radiation by utilizing a large number of cases and permitting more detailed investigations on several potential risk factors, which are costlier to investigate in cohort studies.

For some types of exams, there are no available thyroid dose estimates available in current literature, especially during childhood. This disadvantage could decrease the precision of our estimates; consequently, to harmonize our analyses we considered the same doses for all children older than 2 years. The simplest way to account for age variation of radiation dose exposure (0-2 years compared to older) in our analysis, has probably a limited effect because the reference doses were the same for cases and controls. Thyroid dose estimates were based on self-declarations of diagnostic exam history. In this data, dates for each exam are not precise, causing the impossibility to impose a lagging period and raising the problem of reverse causation. Despite the

439 absence of specific dates for each procedure, we only kept data from radiological 440 procedures that were not carried out for diagnosing thyroid cancer. There is some 441 heterogeneity in demographic and cancer characteristics between our two studies: 442 patients from the Young-Thyr study were younger at cancer diagnosis and inclusion in 443 the study compared to cases from CATHY. Furthermore, diagnostic radiology 444 technologies that were available in childhood differ substantially between the participants 
445 of the CATHY and Young-Thyr studies; additionally, the availability and frequency of 446 these examinations differ (Supplementary Tables S2, S3, and S4). To better discern 447 signals from the genetic analysis and to increase the statistical power, we chose to perform a meta-analysis to substantiate homologous signals in both studies by keeping a 449 limited number of SNPs in this step to avoid a high number of tests.

450

451

452

453

454

455

456

457

458

459

460

461

462

463

464

Despite the small size of our study populations, our results suggest a role for NFATC2, CHD2, RPA3, and ENOSF1/THYS that has not previously been associated with DTC risk and confirm the previously demonstrated role of RAD51B and MGMT. However, functional and validation studies are needed to better understand and confirm the biological role of these variants.

\section{Conclusion}

We present evidence that DTC risk is significantly increased in higher thyroid radiation doses received during childhood from radio diagnostic examinations. In addition, we demonstrated an interaction between this thyroid radiation dose and the minor allele of rs706830 located in MGMT. Our results also suggest an association between polymorphisms in NFATC2, CHD2, ENOSF1/THYS, RPA3, and RAD51B. Taken together, despite the limited size of both populations studied, these results underline the role of DNA repair pathways in DTC risk. More studies of larger populations are needed to validate and characterize the interaction between DNA repair genes and exposure to low IR doses.

Acknowledgement:

FDV received the following grants as principal investigator of Young-Thyr study: Fondation de France (Grant number 65391), L'Alliance pour les sciences de la vie et de la santé, «AVIESAN » (Grants number ENV201416 and 2007005070), the Ligue Nationale Contre le Cancer (LNCC) (Grants number EPDAC6036, EPDTP6004, R10127LL). 
TT received the following grants for CATHY and Young-Thyr studies genotyping Institut National du Cancer (Grant number 9533), the ARC foundation (Grant number PGA120150202302)

$\mathrm{MZ}$ performed this work during her $\mathrm{PhD}$ funded by Ecole des Hautes Etudes en Santé Publique (EHESP) and the ARC Foundation (Grant number ARCDOC42020070002532).

The funders had no role in study design, data collection and analysis, decision to publish, or preparation of the manuscript.

We would like to thank the CEPH-Biobank team, Informatique et Statistique en Anatomie Pathologique en Provence-Alpes-Côte d'Azur (CRISAP PACA) team, as well as Dr C Sattonnet, Dr JL Lassalle, Dr Z Hafdi-Nejjari, Dr P Delafosse, Ms Kami-Marie Moreau, Ms Cyrielle Orenes, Ms Laurianne Sarrazin, Ms Stéphanie Bonnay, Ms Frédérique Chatelain, Ms Maryse Barouh, Ms Evelyne Rapp, Ms Julie Festraëts, Ms Julie Valbousquet, Mr Yusuf Atilgan, Mr Jean Chappellet, Ms Lallia Bedhouche, Mr Florent Dayet and Ms Ziyan Fami for their involvement in Young-Thyr study.

\section{References}

1. Siegel RL, Miller KD, Jemal A. Cancer statistics, 2016. CA Cancer J Clin [Internet]. 2016 [cited 2018 Feb 22];66:7-30. Available from: http://doi.wiley.com/10.3322/caac.21332

2. Vanderpump MP, Vanderpump MPJ. The epidemiology of thyroid disease. 2011 [cited 2019 May 1]; Available from: https://www.researchgate.net/publication/51619844

3. Stepanenko VF, Voillequé PG, Gavrilin YI, Khrouch VT, Shinkarev SM, Orlov MY, et al. Estimating individual thyroid doses for a case-control study of childhood thyroid cancer in Bryansk Oblast, Russia. Radiat Prot Dosimetry. 2004;108:143-60.

4. Modan B, Ron E, Werner a. Thyroid cancer following scalp irradiation. Radiology [Internet]. 1977;123:741-4. Available from: http://www.ncbi.nlm.nih.gov/pubmed/11550916

5. Thomas GA, Bethel JA, Galpine A, Mathieson W, Krznaric M, Unger K. Integrating Research on Thyroid Cancer after Chernobyl - The Chernobyl Tissue Bank. Clin Oncol. $2011 ; 23: 276-81$.

6. Inskip PD, Sigurdson AJ, Veiga L, Bhatti P, Ronckers C, Rajaraman P, et al. RadiationRelated New Primary Solid Cancers in the Childhood Cancer Survivor Study: Comparative Radiation Dose Response and Modification of Treatment Effects. Int J Radiat Oncol 
[Internet]. Elsevier; 2016 [cited 2018 Mar 9];94:800-7. Available from: /pmc/articles/PMC5011040/?report=abstract

7. Memon A, Godward S, Williams D, Siddique I, Al-Saleh K. Dental x-rays and the risk of thyroid cancer: A case-control study. Acta Oncol (Madr). 2010;

8. Cardis E, Kesminiene A, Ivanov V, Malakhova I, Shibata Y, Khrouch V, et al. Risk of thyroid cancer after exposure to 131 I in childhood. J Natl Cancer Inst. 2005;

9. Ron E, Lubin JH, Shore RE, Mabuchi K, Modan B, Pottern LM, et al. Thyroid cancer after exposure to external radiation: A pooled analysis of seven studies. Radiat Res [Internet]. 1995 [cited 2018 Mar 9];141:259. Available from: https://pdfs.semanticscholar.org/458b/269115db3599d129db1e5ea262797801ecf4.pdf

10. Veiga LHSS, Lubin JH, Anderson H, De Vathaire F, Tucker M, Bhatti P, et al. A pooled analysis of thyroid cancer incidence following radiotherapy for childhood cancer. Radiat Res [Internet]. Radiation Research Society; 2012 [cited 2019 Jul 22];178:365-76. Available from: http://www.bioone.org/doi/10.1667/RR2889.1

11. Lubin JH, Adams MJ, Shore R, Holmberg E, Schneider AB, Hawkins MM, et al. Thyroid Cancer Following Childhood Low-Dose Radiation Exposure: A Pooled Analysis of Nine Cohorts. J Clin Endocrinol Metab [Internet]. Oxford University Press; 2017 [cited 2018 Feb 2];102:2575-83. Available from: https://watermark.silverchair.com/jc.20163529.pdf?token=AQECAHi208BE490oan9kkhW_Ercy7Dm3ZL_9Cf3qfKAc485ysgAAAcA wggG8BgkqhkiG9w0BBwagggGtMIIBqQIBADCCAaIGCSqGSIb3DQEHATAeBglghkgBZQ MEAS4wEQQMrRtJ0z4bOGsSwgHqAgEQgllBc_k2gqTLY7sh3b_MfRg1yTu7gaJNIAXNvOJtfMUOc

12. Furukawa K, Preston D, Funamoto S, Yonehara S, Ito M, Tokuoka S, et al. Long-term trend of thyroid cancer risk among Japanese atomic-bomb survivors: 60 years after exposure. Int J Cancer [Internet]. John Wiley \& Sons, Ltd; 2013 [cited 2019 Feb 27];132:1222-6. Available from: http://doi.wiley.com/10.1002/ijc.27749

13. Leung AM. Low-Dose Childhood Radiation Effects to the Thyroid Follow a Linear DoseResponse Trend and Persist Even 45+ Years After Exposure. Clin Thyroidol [Internet]. 2017 [cited 2018 Mar 9];29:235-6. Available from: http://online.liebertpub.com/doi/10.1089/ct.2017\%3B29.235-236

14. Mazonakis M, Tzedakis A, Damilakis J, Gourtsoyiannis N. Thyroid dose from common head and neck CT examinations in children: is there an excess risk for thyroid cancer induction? Eur Radiol [Internet]. Springer-Verlag; 2007 [cited 2018 Mar 9];17:1352-7. 
Available from: http://link.springer.com/10.1007/s00330-006-0417-9

15. Mahaney BL, Meek K, Lees-Miller SP. Repair of ionizing radiation-induced DNA doublestrand breaks by non-homologous end-joining. Biochem J [Internet]. Portland Press Limited; 2009 [cited 2018 Nov 8];417:639-50. Available from: http://www.ncbi.nlm.nih.gov/pubmed/19133841

16. Bhatti P, Yong LC, Doody MM, Preston DL, Kampa DM, Ramsey MJ, et al. Diagnostic Xray examinations and increased chromosome translocations: evidence from three studies NIH Public Access. Radiat Env Biophys. 2010;49:685-92.

17. Sandler JE, Huang H, Zhao N, Wu W, Liu F, Ma S, et al. Germline Variants in DNA Repair Genes, Diagnostic Radiation, and Risk of Thyroid Cancer. Cancer Epidemiol Biomarkers Prev [Internet]. American Association for Cancer Research; 2018 [cited 2018 Mar 9];27:285-94. Available from: http://www.ncbi.nlm.nih.gov/pubmed/29263185

18. Zidane M, Cazier J-BJ-BB, Chevillard S, Ory C, Schlumberger M, Dupuy C, et al. Genetic susceptibility to radiation-related differentiated thyroid cancers: A systematic review of literature [Internet]. Endocr. Relat. Cancer BioScientifica Ltd.; Oct, 2019 page R583-96. Available from: https://erc.bioscientifica.com/view/journals/erc/26/10/ERC-19-0321.xml

19. Cordina-Duverger E, Leux C, Neri M, Tcheandjieu C, Guizard A-V, Schvartz C, et al. Hormonal and reproductive risk factors of papillary thyroid cancer: A population-based case-control study in France. Cancer Epidemiol [Internet]. 2017 [cited 2019 May 1];48:7884. Available from: https://linkinghub.elsevier.com/retrieve/pii/S1877782117300474

20. Xhaard C, Rubino C, Cléro E, Maillard S, Ren Y, Borson-Chazot F, et al. Menstrual and reproductive factors in the risk of differentiated thyroid carcinoma in young women in France: A population-based case-control study. Am J Epidemiol [Internet]. Narnia; 2014 [cited 2019 May 1];180:1007-17. Available from: https://academic.oup.com/aje/articlelookup/doi/10.1093/aje/kwu220

21. Chang L, Miller D, Lee C, Melo D, Villoing D, Drozdovitch V, et al. Thyroid Radiation Dose to Patients from Diagnostic Radiology Procedures over Eight Decades: 1930-2010. Health Phys [Internet]. NIH Public Access; 2017 [cited 2019 May 10];113:458-73. Available from: http://www.ncbi.nlm.nih.gov/pubmed/28968349

22. Amos Cl, Dennis J, Wang Z, Byun J, Schumacher FR, Gayther SA, et al. The oncoarray consortium: A network for understanding the genetic architecture of common cancers. Cancer Epidemiol Biomarkers Prev. American Association for Cancer Research Inc.; 2017;26:126-35. 
23. Li Y, Byun J, Cai G, Xiao X, Han Y, Cornelis O, et al. FastPop: A rapid principal component derived method to infer intercontinental ancestry using genetic data. BMC Bioinformatics [Internet]. BioMed Central Ltd.; 2016 [cited 2020 Mar 6];17:122. Available from: http://www.biomedcentral.com/1471-2105/17/122

24. Ashburner M, Ball CA, Blake JA, Botstein D, Butler H, Cherry JM, et al. Gene ontology: Tool for the unification of biology. Nat. Genet. 2000. page 25-9.

25. Carbon S, Douglass E, Dunn N, Good B, Harris NL, Lewis SE, et al. The Gene Ontology Resource: 20 years and still GOing strong. Nucleic Acids Res. Oxford University Press; 2019;47:D330-8.

26. Berrington de Gonzalez A, Daniels RD, Cardis E, Cullings HM, Gilbert E, Hauptmann M, et al. Epidemiological Studies of Low-Dose lonizing Radiation and Cancer: Rationale and Framework for the Monograph and Overview of Eligible Studies. J Natl Cancer Inst Monogr [Internet]. NLM (Medline); 2020 [cited 2021 Feb 4];2020:97-113. Available from: https://pubmed-ncbi-nlm-nih-gov.proxy.insermbiblio.inist.fr/32657348/

27. Akaike H. Information Theory and an Extension of the Maximum Likelihood Principle BT Selected Papers of Hirotugu Akaike. Second Int Symp Inf Theory. 1973.

28. Willer CJ, Li Y, Abecasis GR. METAL: fast and efficient meta-analysis of genomewide association scans. Bioinformatics [Internet]. 2010 [cited 2020 Jan 12];26:2190-1. Available from: https://academic.oup.com/bioinformatics/articlelookup/doi/10.1093/bioinformatics/btq340

29. Benjamini Y, Hochberg Y. Controlling the False Discovery Rate: A Practical and Powerful Approach to Multiple Testing. J R Stat Soc Ser B. Wiley; 1995;57:289-300.

30. Hunt SE, Mclaren W, Gil L. Ensembl variation resources. Database [Internet]. 2018 [cited 2020 Mar 9];2018:1-12. Available from: https://academic.oup.com/database/articleabstract/doi/10.1093/database/bay119/5255129

31. Pruim RJ, Welch RP, Sanna S, Teslovich TM, Chines PS, Gliedt TP, et al. LocusZoom: regional visualization of genome-wide association scan results. Bioinforma Appl NOTE [Internet]. 2010 [cited 2020 Mar 9];26:2336-7. Available from: http://genome.ucsc.edu/.

32. Little MP, Lim H, Friesen MC, Preston DL, Doody MM, Sigurdson AJ, et al. Assessment of thyroid cancer risk associated with radiation dose from personal diagnostic examinations in a cohort study of US radiologic technologists, followed 1983-2014. BMJ Open [Internet]. British Medical Journal Publishing Group; 2018 [cited 2019 May 10];8:e021536. Available from: http://www.ncbi.nlm.nih.gov/pubmed/29764888 
600

601

602

603

604

605

606

607

608

609

610

611

612

613

614

615

616

617

618

619

620

621

622

623

624

625

626

627

628

629

630

631

33. Nagarajan P, Onami TM, Rajagopalan S, Kania S, Donnell R, Venkatachalam S. Role of chromodomain helicase DNA-binding protein 2 in DNA damage response signaling and tumorigenesis. Oncogene. 2009;28:1053-62.

34. Rajagopalan S, Nepa J, Venkatachalam S. Chromodomain helicase DNA-binding protein 2 affects the repair of X-ray and UV-Induced DNA damage. Environ Mol Mutagen. 2012;53:44-50.

35. Beals CR, Sheridan CM, Turck CW, Gardner P, Crabtree GR. Nuclear export of NF-ATC enhanced by glycogen synthase kinase-3. Science (80- ). 1997;275:1930-3.

36. Flockhart RJ, Diffey BL, Farr PM, Lloyd J, Reynolds NJ. NFAT regulates induction of COX2 and apoptosis of keratinocytes in response to ultraviolet radiation exposure. FASEB $\mathrm{J}$ [Internet]. 2008 [cited 2020 Feb 4];22:4218-27. Available from:

http://www.fasebj.org/doi/10.1096/fj.08-113076

37. Glover D, Little JB, Lavin MF, Gueven N. Low dose ionizing radiation-induced activation of connexin 43 expression. Int J Radiat Biol. 2003;79:955-64.

38. Perotti V, Baldassari P, Molla A, Vegetti C, Bersani I, Maurichi A, et al. NFATc2 is an intrinsic regulator of melanoma dedifferentiation. Oncogene. Nature Publishing Group; 2016;35:2862-72.

39. Kim GC, Kwon HK, Lee CG, Verma R, Rudra D, Kim T, et al. Upregulation of Ets1 expression by NFATc2 and NFKB1/RELA promotes breast cancer cell invasiveness. Oncogenesis. Nature Publishing Group; 2018;7.

40. Damani Shah H, Saranath D, Pradhan S. Single nucleotide polymorphisms in transcription factor genes associated with susceptibility to oral cancer. J Cell Biochem. Wiley-Liss Inc.; 2020;121:1050-60.

41. Lang T, Ding X, Kong L, Zhou X, Zhang Z, Ju H, et al. NFATC2 is a novel therapeutic target for colorectal cancer stem cells. Onco Targets Ther. Dove Medical Press Ltd.; 2018;11:6911-24.

42. Havre PA, Rice MC, Noe M, Kmiec EB. The human REC2/RAD51B gene acts as a DNA damage sensor by inducing G1 delay and hypersensitivity to ultraviolet irradiation. Cancer Res. American Association for Cancer Research; 1998;58:4733-9.

43. Takata M, Sasaki MS, Sonoda E, Fukushima T, Morrison C, Albala JS, et al. The Rad51 Paralog Rad51B Promotes Homologous Recombinational Repair. Mol Cell Biol. American Society for Microbiology; 2000;20:6476-82. 
44. Lee PS, Fang J, Jessop L, Myers T, Raj P, Hu N, et al. Rad51b activity and cell cycle regulation in response to DNA damage in breast cancer cell lines. Breast Cancer Basic Clin Res [Internet]. Libertas Academica Ltd.; 2014 [cited 2020 Mar 6];8:135-44. Available from: http://journals.sagepub.com/doi/10.4137/BCBCR.S17766

45. Pelttari LM, Khan S, Vuorela M, Kiiski JI, Vilske S, Nevanlinna V, et al. RAD51B in Familial Breast Cancer. Brusgaard K, editor. PLoS One [Internet]. Public Library of Science; 2016 [cited 2020 Mar 6];11:e0153788. Available from: https://dx.plos.org/10.1371/journal.pone.0153788

46. Xu WH, Long JR, Zheng W, Ruan ZX, Cai Q, Cheng JR, et al. Association of thymidylate synthase gene with endometrial cancer risk in a chinese population. Cancer Epidemiol Biomarkers Prev [Internet]. American Association for Cancer Research; 2009 [cited 2020 Nov 3];18:579-84. Available from: http://www.hapmap.org

47. Kelemen L, Earp M, Fridley B, Chenevix-Trench G, Fasching P, Beckmann M, et al. rs495139 in the TYMS-ENOSF1 Region and Risk of Ovarian Carcinoma of Mucinous Histology. Int J Mol Sci [Internet]. MDPI AG; 2018 [cited 2020 Nov 3];19:2473. Available from: http://www.mdpi.com/1422-0067/19/9/2473

48. Dai Z, Wang S, Zhang W, Yang Y. Elevated Expression of RPA3 Is Involved in Gastric Cancer Tumorigenesis and Associated with Poor Patient Survival. Dig Dis Sci [Internet]. Springer New York LLC; 2017 [cited 2020 Nov 3];62:2369-75. Available from: https://link.springer.com/article/10.1007/s10620-017-4696-6

49. Lonjou C, Damiola F, Moissonnier M, Durand G, Malakhova I, Masyakin V, et al. Investigation of DNA repair-related SNPs underlying susceptibility to papillary thyroid carcinoma reveals MGMT as a novel candidate gene in Belarusian children exposed to radiation. BMC Cancer [Internet]. BMC Cancer; 2017;17:328. Available from: http://bmccancer.biomedcentral.com/articles/10.1186/s12885-017-3314-5

50. Auton A, Abecasis GR, Altshuler DM, Durbin RM, Bentley DR, Chakravarti A, et al. A global reference for human genetic variation [Internet]. Nature. Nature Publishing Group; 2015 [cited 2020 Mar 9]. page 68-74. Available from: https://www.nature.com/articles/nature15393

51. Heß J, Thomas G, Braselmann H, Bauer V, Bogdanova T, Wienberg J, et al. Gain of chromosome band $7 q 11$ in papillary thyroid carcinomas of young patients is associated with exposure to low-dose irradiation. Proc Natl Acad Sci U S A [Internet]. Proc Natl Acad Sci U S A; 2011 [cited 2020 Dec 30];108:9595-600. Available from: https://pubmed-ncbinIm-nih-gov.proxy.insermbiblio.inist.fr/21606360/ 
52. Hallquist $A$, Jansson $P$. Self-reported diagnostic $X$-ray investigation and data from medical records in case-control studies on thyroid cancer: evidence of recall bias? Eur J Cancer Prev [Internet]. 2005 [cited 2020 Feb 18];14:271-6. Available from: http://www.ncbi.nlm.nih.gov/pubmed/15901997

53. Xhaard C, Dumas A, Souchard V, Ren Y, Borson-Chazot F, Sassolas G, et al. Are dietary reports in a case-control study on thyroid cancer biased by risk perception of Chernobyl fallout? Rev Epidemiol Sante Publique [Internet]. 2017;65:301-8. Available from: https://linkinghub.elsevier.com/retrieve/pii/S0398762017304017 
Author Manuscript Published OnlineFirst on April 7, 2021; DOI: 10.1158/1055-9965.EPI-20-1142

Author manuscripts have been peer reviewed and accepted for publication but have not yet been edited.

Table 1 References used for thyroid radiation dose estimates per diagnostic procedure type

\begin{tabular}{|c|c|c|c|c|c|}
\hline \multirow{3}{*}{ Exams types } & \multicolumn{4}{|c|}{ Doses in $\mathrm{mGy}$} & \multirow[t]{3}{*}{ References } \\
\hline & \multirow{2}{*}{$\begin{array}{c}\text { Childhood exposure } \\
\text { age }<2\end{array}$} & \multicolumn{3}{|c|}{ Childhood exposure age $>2$ years and adulthood exams } & \\
\hline & & Before 1980 & 1980-1989 & 1990 and after & \\
\hline \multicolumn{6}{|l|}{ Conventional Radiography } \\
\hline Skull & -8 & 3.6 & 3.6 & 0.42 & Chang et al. 2017 \\
\hline Dental (panoramic) & $-\$$ & 0.56 & 0.07 & 0.02 & Chang et al. 2017 \\
\hline Paranasal sinuses & -8 & 0.02 & 0.04 & 0.04 & Chang et al. 2017 \\
\hline Intravenous urography & $0.38^{*}$ & 0.38 & 0.21 & 0.21 & Inskip et al. 1995 \\
\hline Chest & 0.13 & 0.16 & 0.31 & 0.19 & Almén and Mattsson 1995 / Chang et al. 2017 \\
\hline Spine & $2.8^{*}$ & 2.8 & 4.5 & 0.99 & Chang et al. 2017 \\
\hline \multicolumn{6}{|l|}{ CT Scan } \\
\hline Skull & 3 & 0.43 & 0.49 & 0.64 & Lee et al. 2007 / Chang et al. 2017 \\
\hline Chest & 5.9 & 15 & 20.5 & 22 & Mabille et al. 2008 / Chang et al. 2017 \\
\hline Spine & 13.5 & 17 & 24 & 25.5 & Mabille et al. 2008 / Chang et al. 2017 \\
\hline Abdomen & 0.17 & 0.28 & 0.38 & 0.41 & Mabille et al. 2008 / Chang et al. 2017 \\
\hline \multicolumn{6}{|l|}{ Nuclear medicine } \\
\hline Bone scan & $1.1 *$ & 1.1 & 0.96 & 1.1 & Chang et al. 2017 \\
\hline Brain scan & -8 & 1.3 & 3.6 & 9 & Chang et al. 2017 \\
\hline Lung scan (perfusion/ventilation) & $-\S$ & 0.2 & 0.25 & 0.25 & Chang et al. 2017 \\
\hline Heart scan & -8 & 11 & 17 & 12 & Chang et al. 2017 \\
\hline Liver scan & $-\$$ & 0.15 & 0.15 & 0.15 & Chang et al. 2017 \\
\hline Renal scan & -8 & 0.17 & 0.31 & 0.17 & Chang et al. 2017 \\
\hline
\end{tabular}

$\S$ : No exposed subject at this age

*: No available data for children, adult data used 
Table 2 Clinical and demographic description of the population included in DTC risk in relation to thyroid radiation doses analysis and genetic analysis

\begin{tabular}{|c|c|c|c|c|}
\hline & \multicolumn{2}{|c|}{ Whole population } & \multicolumn{2}{|c|}{ The population included in the genetic analysis } \\
\hline & Cases $(n=1393)$ & Controls $(n=1580)$ & Cases $(n=1072)$ & Controls $(n=1188)$ \\
\hline \multicolumn{5}{|l|}{ Gender (\%) } \\
\hline Men & $300(21.5)$ & $398(25.2)$ & $228(21.3)$ & $302(25.4)$ \\
\hline Women & $1093(78.5)$ & $1182(74.8)$ & $844(78.7)$ & $886(74.6)$ \\
\hline \multicolumn{5}{|c|}{ Age at diagnosis/reference year (years) } \\
\hline Mean & 37.58 & 37.21 & $37.4(15.0)$ & $37.6(15.2)$ \\
\hline Median [Min, Max] & $32.0[9.00,83.0]$ & $32.0[9.00,83.0]$ & $32.0[11.0,83.0]$ & $32.0[9.00,80.0]$ \\
\hline \multicolumn{5}{|l|}{ Smoking status (\%) } \\
\hline Non-smoker & $739(53.1)$ & $768(48.6)$ & $232(52.4)$ & $271(50.9)$ \\
\hline Former smoker & $304(21.8)$ & $306(19.4)$ & $140(31.6)$ & $149(28.0)$ \\
\hline Smoker & $350(25.1)$ & $506(32.0)$ & $71(16.0)$ & $112(21.1)$ \\
\hline \multicolumn{5}{|c|}{ Alcohol consumption (Number of alcohol glasses per week) (\%) } \\
\hline No consumption & \multicolumn{2}{|c|}{$778(55.9) \quad 763(48.3)$} & $582(54.3)$ & $559(47.1)$ \\
\hline Less than 10 & 504 (36.2) & $673(42.6)$ & $403(37.6)$ & $521(43.9)$ \\
\hline More than 10 & $110(7.9)$ & $144(9.1)$ & $87(8.1)$ & $108(9.1)$ \\
\hline \multicolumn{5}{|l|}{ BMI $\left(\mathrm{Kg} / \mathrm{m}^{2}\right)$} \\
\hline Mean (SD) & $24.6(5.21)$ & $24.1(4.88)$ & $24.7(5.36)$ & $24.2(4.89)$ \\
\hline Median [Min, Max] & $23.5[11.0,51.8]$ & $23.1[13.4,49.1]$ & $23.6[11.0,51.8]$ & $23.1[13.4,48.7]$ \\
\hline \multicolumn{5}{|l|}{ Goitre history (\%) } \\
\hline No & $899(64.5)$ & $1468(92.9)$ & $695(64.8)$ & $1102(92.8)$ \\
\hline Yes & $494(35.5)$ & $112(7.1)$ & 377 (35.2) & $86(7.2)$ \\
\hline \multicolumn{5}{|c|}{ Thyroid cancer family history (\%) } \\
\hline No & $1542(97.6)$ & $1322(94.9)$ & $1023(95.4)$ & $1158(97.5)$ \\
\hline Yes & $38(2.4)$ & $71(5.1)$ & $49(4.6)$ & $30(2.5)$ \\
\hline \multicolumn{5}{|l|}{ Radiotherapy history (\%) } \\
\hline No & $1558(98.6)$ & 1354 (97.2) & $1043(97.3)$ & 1168 (98.3) \\
\hline Yes & $29(2.8)$ & $22(1.3)$ & $19(1.7)$ & $20(1.6)$ \\
\hline \multicolumn{5}{|l|}{ Educational level (\%) } \\
\hline Bachelor's degree or higher & $765(54.9)$ & $982(62.2)$ & $618(57.6)$ & $743(62.5)$ \\
\hline Secondary school & $418(30.0)$ & $406(25.7)$ & $315(29.4)$ & $311(26.2)$ \\
\hline Primary school level & $210(15.1)$ & $192(12.2)$ & $139(13.0)$ & $134(11.3)$ \\
\hline Childhood thyroid radiatio & in $\mathrm{mGy}(\%)$ & & & \\
\hline 0 & $1021(73.3)$ & $1161(73.5)$ & $777(72.5)$ & $876(73.7)$ \\
\hline ]0,1] & $112(8.0)$ & $147(9.3)$ & $89(8.3)$ & $104(8.8)$ \\
\hline ]1,5] & $139(10.0)$ & $150(9.5)$ & $116(10.8)$ & $113(9.5)$ \\
\hline$] 5,10]$ & $25(1.8)$ & $45(2.8)$ & $18(1.7)$ & $36(3.0)$ \\
\hline$] 10,20]$ & $49(3.5)$ & $57(3.6)$ & $35(3.3)$ & $42(3.5)$ \\
\hline$>20$ & $46(3.3)$ & $20(1.3)$ & $37(3.5)$ & $17(1.4)$ \\
\hline Mean (sd) & $2.79(10.3)$ & $1.98(6.18)$ & $2.89(11.1)$ & $2.11(6.62)$ \\
\hline Median [Min, Max] & $0[0,194]$ & $0[0,80.9]$ & $0[0,194]$ & $0[0,80.9]$ \\
\hline Adulthood thyroid radiatio & in $\mathrm{mGy}(\%)$ & & & \\
\hline 0 & $669(48.1)$ & $797(50.4)$ & $523(48.8)$ & $591(49.7)$ \\
\hline ]0,1] & $247(17.7)$ & $283(17.9)$ & $187(17.4)$ & $220(18.5)$ \\
\hline ]1,5] & $245(17.6)$ & $262(16.6)$ & $182(17.0)$ & $193(16.2)$ \\
\hline j5,10] & $59(4.2)$ & $61(3.9)$ & $46(4.3)$ & $46(3.9)$ \\
\hline ]10,20] & $53(3.8)$ & $43(2.7)$ & $44(4.1)$ & $35(2.9)$ \\
\hline$>20$ & $119(8.5)$ & $134(8.5)$ & $90(8.4)$ & $103(8.7)$ \\
\hline Mean $(\mathrm{sd})$ & $5.63(17.3)$ & $5.50(17.9)$ & $5.28(16.6)$ & $5.54(17.2)$ \\
\hline Median [Min, Max] & $0[0,245]$ & $0.02[0,262]$ & $0.02[0,245]$ & $0.02[0,157]$ \\
\hline Number of children (\%) & & & & \\
\hline 0 (and men) & $666(47.8)$ & $829(52.5)$ & $514(47.9)$ & $622(52.4)$ \\
\hline $1-3$ & $648(46.6)$ & $529(43.8)$ & $542(50.6)$ & $542(45.6)$ \\
\hline $4-6$ & $67(4.8)$ & $44(3.4)$ & $10(0.9)$ & $20(1.7)$ \\
\hline$>6$ & $11(0.4)$ & $4(0.3)$ & $6(0.6)$ & $4(0.3)$ \\
\hline Study & & & & \\
\hline Young-Thyr (\%) & $805(57.8)$ & $876(55.4)$ & $629(58.7)$ & $656(55.2)$ \\
\hline Cathy $(\%)$ & $587(42.2)$ & $704(44.6)$ & $443(41.3)$ & $532(44.8)$ \\
\hline Thyroid cancer histology ( & & & & \\
\hline Follicular & $140(10.1)$ & & $109(10.2)$ & \\
\hline Papillary & $1243(89.2)$ & & $955(89.1)$ & \\
\hline Missing & $10(0.7)$ & & $8(0.7)$ & \\
\hline Thyroid cancer size in $\mathrm{mm}$ & & & & \\
\hline$<10$ & $431(31.0)$ & & $341(31.8)$ & \\
\hline$>10$ & $957(68.8)$ & & $729(68.0)$ & \\
\hline Missing & $4(0.28)$ & & $2(0.2)$ & \\
\hline
\end{tabular}


Table 3 Number of subjects by age and exam type

\begin{tabular}{|l|c|c|c|c|}
\hline \multirow{2}{*}{} & \multicolumn{2}{|c|}{ Cases n (\%) having at least 1 listed exam } & \multicolumn{2}{c|}{ Controls n (\%) having at least 1 listed exam } \\
\cline { 2 - 5 } & $<20$ years & $>=20$ years & $<20$ years & $>=20$ years \\
\hline Conventional radiography & \multicolumn{5}{|l|}{} \\
\hline Skull & $89(6.4)$ & $93(6.7)$ & $94(5.9)$ & $82(5.2)$ \\
\hline Sinus & $67(4.8)$ & $124(8.9)$ & $77(4.9)$ & $133(8.4)$ \\
\hline Dental & $416(29.9)$ & $260(18.7)$ & $555(35.1)$ & $309(19.6)$ \\
\hline Spine & $180(12.9)$ & $277(19.9)$ & $199(12.6)$ & $296(18.7)$ \\
\hline Chest & $159(11.4)$ & $451(32.4)$ & $198(12.5)$ & $465(29.4)$ \\
\hline Intravenous urography & $27(1.9)$ & $94(6.7)$ & $31(2.0)$ & $74(4.7)$ \\
\hline CT scan & $7(0.5)$ & $47(3.4)$ & $2(0.1)$ & $33(2.1)$ \\
\hline Abdomen & $8(0.6)$ & $46(3.3)$ & $0(0)$ & $33(2.1)$ \\
\hline Chest & $53(3.8)$ & $137(9.8)$ & $47(3.0)$ & $117(7.4)$ \\
\hline Skull & $31(2.22)$ & $122(8.75)$ & $29(1.83)$ & $160(10.12)$ \\
\hline Spine & $1(0.1)$ & $3(0.2)$ & $0(0)$ & $9(0.6)$ \\
\hline Nuclear medicine & $1(0.1)$ & $2(0.1)$ & $1(0.1)$ & $7(0.4)$ \\
\hline Cerebral & $1(0.1)$ & $3(0.2)$ & $0(0)$ & $7(0.4)$ \\
\hline Heart & $8(0.6)$ & $43(3.1)$ & $6(0.4)$ & $52(3.3)$ \\
\hline Lung & $0(0)$ & $2(0.1)$ & $0(0)$ & $2(0.1)$ \\
\hline Bones & $4(0.3)$ & $5(0.4)$ & $5(0.3)$ & $13(0.8)$ \\
\hline Hepatic & & & \\
\hline Renal &
\end{tabular}


Table 4: Dose-response analysis for thyroid radiation dose: - Whole population and subgroups

\begin{tabular}{|c|c|c|c|c|c|c|c|c|c|c|c|c|}
\hline & \multicolumn{4}{|c|}{$\begin{array}{l}\text { Whole population: Adjusted analysis } \\
\end{array}$} & \multicolumn{4}{|c|}{ Only micro-carcinomas cases (431 cases and 1580 controls) } & \multicolumn{4}{|c|}{$\begin{array}{l}\text { Excluding micro-carcinomas cases (962 cases and } 1580 \text { controls) } \\
\end{array}$} \\
\hline & Coefficient $(95 \% \mathrm{CI})$ for $1 \mathrm{mGy}$ & $\begin{array}{c}\mathrm{OR}^{\mathrm{a}}(\mathbf{9 5 \%} \% \mathrm{CI}) \text { at } \\
1 \mathrm{mGy}\end{array}$ & Deviance & P-value & $\begin{array}{c}\text { Coefficient (95\% Cl) for } 1 \\
\text { mGy }\end{array}$ & $\begin{array}{c}\mathrm{OR}^{\mathrm{a}}(\mathbf{9 5 \%} \mathrm{Cl} \text { ) at } \\
1 \mathrm{mGy}\end{array}$ & Deviance & P-value & $\begin{array}{c}\text { Coefficient }(95 \% \mathrm{Cl} \text { ) for } 1 \\
\text { mGy }\end{array}$ & \begin{tabular}{|c|}
$\mathrm{OR}^{\mathrm{a}}(95 \% \mathrm{CI})$ at \\
$1 \mathrm{mGy}$
\end{tabular} & Deviance & P-value \\
\hline \multicolumn{13}{|l|}{ No radiation dose- } \\
\hline \multicolumn{13}{|c|}{ The radiation dose received during childhood } \\
\hline Linear & $0.017(0.00060,0.035)$ & $1.02(1.00,1.03)$ & 3959.5 & 0.007 & $0.024(-0.0024,0.051)$ & $1.02(1.00,1.05)$ & 2363.6 & 0.008 & $0.015(-0.0041,0.035)$ & $1.01(0.99,1.04)$ & 3025.2 & 0.04 \\
\hline $\begin{array}{lll}\text { Quadratic } \\
\text { Formentiol }\end{array}$ & $\begin{array}{ll}0.00053(-0.000047-0.0011) \\
\end{array}$ & $\frac{1(1.00,1.00)}{101(101.109}$ & 3957.9 & 0.003 & $0.00078(-0.00011,0.0017)$ & $\frac{1(1.00,1.00)}{10.0104)}$ & 2361.8 & 0.003 & $\begin{array}{l}0.00048(-0.00015,0.00079) \\
\end{array}$ & $\frac{1(1.00,1.00)}{10000}$ & 3024 & 0.02 \\
\hline \multirow{2}{*}{\multicolumn{13}{|c|}{ The radiation dose received during adulthood }} \\
\hline & & & & & & & & & & & & \\
\hline Linear & $\begin{array}{l}8.710-5-\left(-6.0 .10^{-4}, 7.7 .10-4\right) \\
-9.110-6\left(-2.60^{-5}, 7.40-6\right)\end{array}$ & $\frac{1(1.00,1.00)}{1(1.00,1.00)}$ & 3966.72 & $>0.9$ & $\frac{-8.610(-3.8 .10,4.0 .10)}{-6.010^{-6}\left(-3.110^{-5}, 1.910^{-5}\right)}$ & $\frac{(0.99,1.01)}{1(1.00,1.00)}$ & $\frac{230.8}{2370.7}$ & $>0.9$ & $\frac{-2.710(-3.410-3.3 .10)}{-1510^{-5}\left(-1.510^{-5} .1510^{-5}\right)}$ & $\frac{1(1.0,1.00)}{1(1.00 .1 .00)}$ & $\frac{3029.4}{3028.5}$ & $>0.9$ \\
\hline Exponential & $1.210-4(-0.0089,0.0091)$ & $1(0.99,1.01)$ & 3966.7 & $>0.9$ & $-1.610^{-3}(-0.014,0.011)$ & $1(0.99,1.01)$ & 2370.8 & $>0.9$ & $-3.410^{-5}(-0.011,0.011)$ & $0.99(0.99,1.01)$ & 3029.4 & $>0.9$ \\
\hline
\end{tabular}

${ }^{\text {a }}$ Stratified on age, sex, and study, and adjusted on thyroid cancer family history, radiotherapy history, BMI, height, smoking habits, and number of pregnancies 
Table 5 SNPs with the lowest p-values associated with DTC risk in the meta-analysis among all DTC

types cases (A), among only papillary DTC cases $(B)$, macrocarcinoma cases $(C)$, and microcarcinoma cases $(D)$

\begin{tabular}{|c|c|c|c|c|c|c|c|c|c|c|c|c|}
\hline \multirow{2}{*}{ SNP } & \multirow{2}{*}{ Locus } & \multirow{2}{*}{ RA } & \multirow{2}{*}{ EA } & \multirow{2}{*}{ EAF } & \multirow{2}{*}{ Gene } & \multicolumn{2}{|c|}{$\begin{array}{l}\text { Young-Thyr } \\
\end{array}$} & \multicolumn{2}{|c|}{ CATHY } & \multicolumn{3}{|c|}{ Meta-analysis } \\
\hline & & & & & & $\mathrm{OR}^{a}$ & P-value & $\mathrm{OR}^{\mathrm{a}}$ & P-value & $\mathrm{OR}^{\mathrm{a}}$ & P-value & FDR p-value \\
\hline rs 12702628 & $7 \mathrm{p} 21.3$ & $\mathrm{~A}$ & $\mathrm{G}$ & 0.4 & $R P A 3$ & 1.25 & $1.0310^{-2}$ & 1.22 & $4.3710^{-2}$ & 1.24 & $1.1210^{-15}$ & 0.02 \\
\hline rs7164173 & $15 \mathrm{q} 26.1$ & $\mathrm{G}$ & $\mathrm{T}$ & 0.1 & CHD2 & 0.7 & $1.0510^{-3}$ & 0.69 & $1.0610^{-2}$ & 0.68 & $9.2610^{-05}$ & 0.004 \\
\hline $\begin{array}{ll}\mathrm{rs} 1059394 \\
\end{array}$ & $18 \mathrm{p} 11.32$ & $\mathrm{C}$ & $\mathrm{T}$ & 0.3 & ENOSFI/THYS & 1.34 & $2.9110^{-3}$ & 1.19 & $8.9710^{-2}$ & 1.3 & $7.8110^{-04}$ & 0.01 \\
\hline $\begin{array}{ll}\mathrm{rs} 699517 \\
\end{array}$ & $18 \mathrm{p} 11.32$ & C & $\mathrm{T}$ & 0.3 & ENOSFI/THYS & 1.34 & $2.9110^{-3}$ & 1.19 & $8.9710^{-2}$ & 1.3 & $7.8110^{-144}$ & 0.01 \\
\hline rs6067822 & $20 \mathrm{q} 13.2$ & $\mathrm{G}$ & $\mathrm{T}$ & 0.3 & NFATc2 & 0.64 & $1.610^{-3}$ & 0.7 & $1.1310^{-3}$ & 0.64 & $5.7910^{-0.5}$ & 0.005 \\
\hline \multicolumn{13}{|c|}{ B/ SNPs with lowest p-values associated with papillary thyroid carcinoma risk in the meta-analysis (563 cases from Young-Thyr and 392 cases from CATHY) } \\
\hline \multirow{2}{*}{ SNP } & \multirow{2}{*}{ Locus } & \multirow{2}{*}{ RA } & \multirow{2}{*}{ EA } & \multirow{2}{*}{ EAF } & \multirow{2}{*}{ Gene } & \multirow{2}{*}{\multicolumn{2}{|c|}{\begin{tabular}{c}
\multicolumn{2}{c}{ Young-Thyr } \\
$\mathrm{OR}^{\mathrm{a}}$ \\
\end{tabular}}} & \multirow{2}{*}{\multicolumn{2}{|c|}{\begin{tabular}{c|c}
\multicolumn{2}{c}{ CATHY } \\
$\mathrm{OR}^{a}$ & P-value
\end{tabular}}} & \multirow{2}{*}{\multicolumn{3}{|c|}{ Meta-analysis }} \\
\hline & & & & & & & P-value & & & $\mathrm{OR}^{\mathrm{a}}$ & & FDR p-value \\
\hline rs1950764 & $14 \mathrm{q} 24.1$ & $\mathrm{G}$ & $\mathrm{A}$ & 0.2 & RAD5IB & 0.56 & $2.8710^{-105}$ & 0.66 & $7.2710^{-12}$ & 0.6 & $6.0810^{-124}$ & 0.01 \\
\hline rs1290997 & $14 \mathrm{q} 24.1$ & $\mathrm{G}$ & $\mathrm{T}$ & 0.2 & RAD5IB & 0.77 & $2.0110^{-03}$ & 0.7 & $7.1810^{-12}$ & 0.74 & $4.3610^{-04}$ & 0.01 \\
\hline rs 7164173 & $15 \mathrm{q} 26.1$ & $\mathrm{G}$ & $\mathrm{T}$ & 0.3 & CHD2 & 0.69 & $3.2410^{-15}$ & 0.68 & $1.0210^{-12}$ & 0.68 & $9.3310^{-159}$ & 0.009 \\
\hline rs77971457 & $20 \mathrm{q} 13.2$ & $\mathrm{G}$ & $\mathrm{T}$ & 0.1 & NFATC2 & 1.44 & $1.0910^{-1.35}$ & 1.47 & $1.7610^{-12}$ & 1.45 & $5.0610^{-04}$ & 0.01 \\
\hline rs6067822 & $20 \mathrm{q} 13.2$ & $\mathrm{G}$ & $\mathrm{T}$ & 0.3 & NFATc2 & 0.81 & $3.4710^{-15}$ & 0.72 & $4.6310^{-12}$ & 0.77 & $5.5910^{-04}$ & 0.01 \\
\hline \multicolumn{13}{|c|}{ C/ SNPs with lowest p-values associated with large thyroid carcinoma (>10 $10 \mathrm{~mm}$ ) risk in the meta-analysis (501 cases from Young-Thyr and 237 cases from CATHY) } \\
\hline \multirow[b]{2}{*}{ SNP } & \multirow{2}{*}{ Locus } & \multirow[b]{2}{*}{ RA } & \multirow[b]{2}{*}{ EA } & \multirow[b]{2}{*}{ EAF } & \multirow[b]{2}{*}{ Gene } & \multicolumn{2}{|c|}{ Young-Thyr } & \multicolumn{2}{|c|}{ CATHY } & & Meta-analysis & \\
\hline & & & & & & $\mathrm{OR}^{\mathrm{a}}$ & P-value & $\mathrm{OR}^{\mathrm{a}}$ & P-value & $\mathrm{OR}^{\mathrm{a}}$ & P-value & FDR p-value \\
\hline rs 72625242 & $2 \mathrm{q} 31.1$ & $\mathrm{C}$ & $\mathrm{T}$ & 0.22 & MLK7-AS1 & 1.927 & $6.2710^{-4}$ & 0.9934 & 1 & 1.927 & $6.2510^{-4}$ & 0.004 \\
\hline rs17619600 & $2 \mathrm{q} 37.1$ & $\mathrm{~T}$ & $\mathrm{C}$ & 0.15 & PMSD1 & 1.855 & $1.2010^{-3}$ & 1.01 & 0.9999 & 1.855 & $1.2010^{-3}$ & 0.004 \\
\hline rs 7578070 & $2 \mathrm{p} 24.2$ & $\mathrm{~A}$ & $\mathrm{G}$ & 0.41 & $\begin{array}{l}\text { SMC6 } \\
\end{array}$ & 1.538 & $1.8610^{3}$ & 1.03 & 0.9998 & 1.538 & $1.8610^{-3}$ & 0.004 \\
\hline rs16861406 & $2 \mathrm{q} 31.1$ & $\mathrm{~A}$ & $\mathrm{G}$ & 0.21 & MLK7-AS1 & 1.912 & $2.5610^{-3}$ & 1.009 & 1 & 1.912 & $2.5610^{-3}$ & 0.005 \\
\hline rs5023821 & $10 \mathrm{q} 26 ; 2$ & $\mathrm{~T}$ & $\mathrm{C}$ & 0.25 & C10orf90 & 0.6249 & $1.1410^{-3}$ & 1.026 & 0.9998 & 0.6249 & $1.1410^{-3}$ & 0.004 \\
\hline & & with & ues as & ith sma & oid carcinoma $(<1$ & 1) risk in & a-analysis & ses from Your & Thyr and 206 & from CATH & & \\
\hline SNP & Locus & RA & EA & EAF & Gene & & & CAT & & & Meta-analysi: & \\
\hline rs75361806 & 20311 & - & & & $\mathrm{T}$ K1 & $\mathrm{OR}^{-}$ & P-value & $\mathrm{OR}^{\prime}$ & P-value & OR & P-value & FDR p-value \\
\hline rs 73234091 & $20 \mathrm{p} 12.1$ & $\mathrm{~T}$ & $\mathrm{C}$ & 0.05 & MACROD2 & 25.55 & $1.1210^{-3}$ & 1.02 & 1 & 25.5494 & $1.1210^{-2}$ & 0.03 \\
\hline rs 17757541 & $18 \mathrm{q} 21.33$ & $\mathrm{C}$ & G & 0.06 & BCL2 & $\frac{70.69}{7.188}$ & $1.2210^{-2}$ & 1.005 & 1 & $\frac{30.001}{7.1877}$ & $1.1210^{-2}$ & 0.03 \\
\hline rs116851051 & $20 \mathrm{p} 12.1$ & $\mathrm{~T}$ & $\mathrm{C}$ & 0.1 & MACROD2 & 28.39 & $1.1210^{-2}$ & 0.9935 & 1 & 28.3897 & $1.1210^{-2}$ & 0.035 \\
\hline rs 2327965 & $20 \mathrm{p} 12.1$ & A & $\mathrm{G}$ & 0.05 & MACROD2 & 27.11 & $1.1210^{-2}$ & 1.016 & 1 & 27.1096 & $1.1210^{-2}$ & 0.03 \\
\hline
\end{tabular}

RA=Reference allele

$\mathrm{EA}=$ Effect allele

$\mathrm{EAF}=$ Effect allele frequency

a: Adjusted on age, sex, childhood IR thyroid doses, thyroid cancer family history, radiotherapy history, goiter history, BMI, height, educational level, smoking status, number of pregnancies, and three first genetic components 
Table 6 Five SNPS with the lowest p-values in SNPs - diagnostic radiation thyroid doses interaction term from the meta-analysis

\begin{tabular}{|c|c|c|c|c|c|c|c|c|c|c|c|c|}
\hline SNP & Locus & $\begin{array}{l}\text { Reference } \\
\text { allele }\end{array}$ & $\begin{array}{l}\text { Effect } \\
\text { allele }\end{array}$ & EAF & Gene & \multicolumn{2}{|c|}{ Young-Thyr } & \multicolumn{2}{|c|}{ CATHY } & \multicolumn{3}{|c|}{ Meta-analysis } \\
\hline rs 17514740 & $7 \mathrm{p} 11.2$ & $\mathrm{G}$ & $\mathrm{C}$ & 0.4 & $E G F R$ & 0.71 & $9.3910^{-033}$ & 1.19 & $1.8410^{-01}$ & 1.30 & $4.6410^{-03}$ & 0.1 \\
\hline rs10402248 & 19p13.3 & $\mathrm{C}$ & $\mathrm{T}$ & 0.4 & MUMI & 0.65 & $4.7910^{-03}$ & 0.85 & $2.5410^{-01}$ & 0.75 & $4.0310^{-03}$ & 0.1 \\
\hline rs6066138 & $20 \mathrm{q} 13.12$ & $\mathrm{G}$ & $\mathrm{A}$ & 0.2 & $E Y A 2$ & 1.52 & $9.7310^{-03}$ & 1.22 & $9.01 \quad 10^{-02}$ & 1.32 & $2.2010^{-03}$ & 0.1 \\
\hline
\end{tabular}

$\mathrm{EAF}=$ Effect allele frequency

$\mathrm{OR}=$ Odds Ratio for the interaction between Effect Allele and radiation dose, considered as a continuous variable in an exponential dose-response model

${ }^{\text {a }}$ : Adjusted on age, sex, thyroid cancer family history, radiotherapy history, goiter history, BMI, height, educational level, smoking status, number of pregnancies, and three first genetic components 


\section{Cancer Epidemiology, Biomarkers \& Prevention}

\section{Role of DNA repair variants and diagnostic radiology exams in differentiated thyroid cancer risk: a pooled-analysis of two case-control studies}

Monia Zidane, Therese Truong, Fabienne Lesueur, et al.

Cancer Epidemiol Biomarkers Prev Published OnlineFirst April 7, 2021. Updated version $\begin{aligned} & \text { Access the most recent version of this article at: } \\ & \text { doi:10.1158/1055-9965. EPI-20-1142 }\end{aligned}$

Supplementary Access the most recent supplemental material at:

Material http://cebp.aacrjournals.org/content/suppl/2021/04/03/1055-9965.EPI-20-1142.DC1

Author Author manuscripts have been peer reviewed and accepted for publication but have not yet Manuscript been edited.

E-mail alerts Sign up to receive free email-alerts related to this article or journal.

Reprints and To order reprints of this article or to subscribe to the journal, contact the AACR Publications

Subscriptions Department at pubs@aacr.org.

Permissions To request permission to re-use all or part of this article, use this link

http://cebp.aacrjournals.org/content/early/2021/04/06/1055-9965.EPI-20-1142.

Click on "Request Permissions" which will take you to the Copyright Clearance Center's (CCC) Rightslink site. 